\title{
APLIKASI ANDROID UNTUK MENINGKATKAN PEMASARAN KERAJINAN ANYAMAN PURUN
}

\author{
Saman Abdurrahman ${ }^{1}$ dan Dodon Turianto ${ }^{2 *}$ \\ ${ }^{122)}$ Prodi Matematika, FMIPA Unlam \\ Jl. A. Yani, Km 36 , Banjarbaru, Kalimantan Selatan \\ *Korespondensi penulis, email: dodonturianto@ulm.ac.id
}

\begin{abstract}
Abstrak: Kerajinan anyaman purun mempunyai nilai ekonomi yang besar. Salah satu kendala dalam pengembangan kerajinan anyaman purun adalah terbatasnya promosi dan pemasaran. Melalui kegiatan KKN-PPM mahasiswa FMIPA ULM membuat aplikasi android untuk membenatu memecahkan masalah tersebut. Aplikasi android tersebut berisi profil aplikasi, galeri, petunjuk dan peta lokasi. Hasil kegiatan menunjukkan peningkatan transaksi sebesar 70\% dalam waktu 3 minggu setelah penggunaan aplikasi dan peningkatan pendapatan sebesar 65\%.
\end{abstract}

Kata Kunci: Anyaman purun, android, Kelurahan Palam

\section{PENDAHULUAN}

Usaha Kecil Menengah (UKM) merupakan salah satu sektor usaha riil yang memiliki peranan penting dan merupakan salah satu tulang punggung perekonomian negara berkembang seperti Indonesia. Namun terdapat beberapa masalah dalam mengembangkan UKM tersebut.

Ketiadaan media untuk mempromosikan produk hasil UKM sebenarnya juga merupakan masalah yang dialami oleh pemberdayaan UKM diseluruh daerah di Indonesia (Gartner 2013). Untuk itu, diperlukan strategi khusus dalam upaya peningkatan daya saing dengan pemanfaatan teknologi informasi dan komunikasi. Karena dengan memanfaatkan teknologi informasi pelaku UKM dapat mengembangkan usahanya sehingga mereka bisa cepat maju dan siap secara global (Amelia et al. 2017).

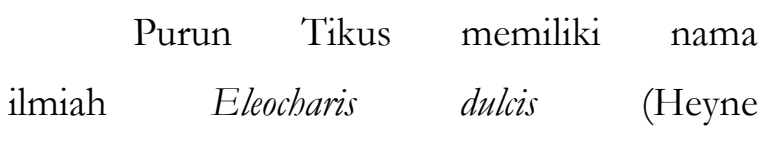

1987). Masyarakat lokal menyebutnya dengan purun tikus. Tumbuhan purun tikus merupakan tanaman khas pada daerah lahan basah. Namun demikian, purun dianggap sebagai gulma pengganggu. Masyarakat Kelurahan Palam memanfaatkan tumbuhan gulma tersebut menjadi kerajinan anyaman yang bernilai ekonomi tinggi. Beberapa produk kerajinan anyaman yang dihasilkan antara lain: tas, tikar, bakul, topi, dan banyak lagi jenis kerajinan lainnya. Hal ini mendorong pemerintah setempat mendirikan Kampung Purun sebagai salah ikon wisata Banjarbaru.

Untuk membantu mengatasi masalah pemasaran dan memaksimalkan potensi kerajinan anyaman purun, Fakultas MIPA ULM melalui kegiatan KKN-PPM membuat 
Jurnal Mediteg

Volume 3, Nomor 1, Desember 2018

aplikasi android untuk memperluas jangkauan pasar kerajinan anyaman purun.

\section{METODE PELAKSANAAN}

Pembuatan aplikasi android dan web diawali dengan pemotretan produk, membuat katalog produk, dan meng input gambar serta harga produk tersebut ke sistem aplikasi dan web, berikutnya adalah pengujian alikasi. Kegiatan pelatihan dan pendampingan juga dilakukan pada pengrajin sehingga mereka mampu merespon dan mengupdate data produk yang dijual. Kegiatan kerja sama dengan jasa pengiriman JNE juga dilakukan, untuk mempermudah proses pengiriman. Kegiatan pelatihan diikuti oleh 10 pengrajin anyaman purun yang ada di kampung purun, kelurahan Palam.

\section{HASIL KEGIATAN}

Penggunaan aplikasi android untuk pemasaran produk hasil UKM merupakan strategi pemasaran dalam menembus pasar bebas ASEAN. Karena keadaan yang ada di masyarakat para produsen UKM masih mengalami masalah dalam proses pemasaran. Sehingga dengan adanya konsep pemasaran berbasis android diharapkan dapat membantu para produsen UKM dalam memasarkan hasil produk mereka (Amelia et al. 2017)
p-ISSN : 2548-7655

e-ISSN : 2614-0489

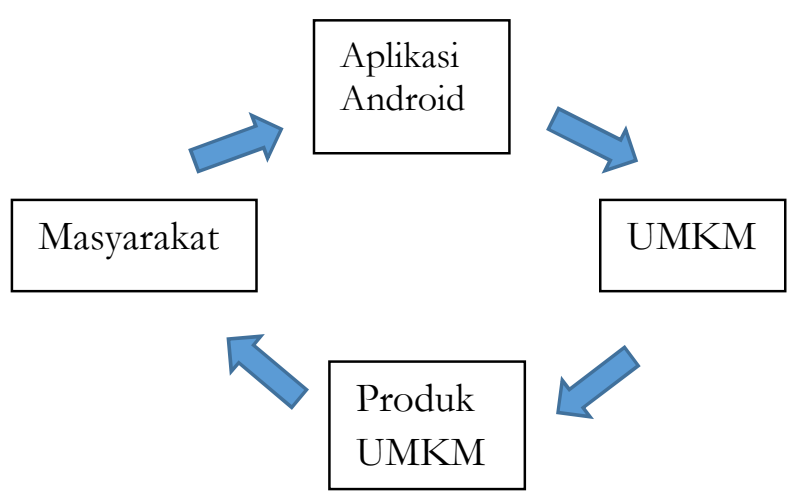

Gambar 1. Model pemasaran setelah aplikasi berjalan

Penjelasan proses pada Gambar 1 adalah sebagai berikut: Pertama, masyarakat sebagai pengguna akan menghubungi pihak UKM. Kedua, pengguna akan menggunakan telepon seluler yang sudah terpasang aplikasi android. Ketiga pengguna akan terhubung ke UKM yang bersangkutan dan memulai transaksi. Produk UKM yang diinginkan oleh pengguna sudah siap untuk dipasarkan kepada pemesan. Produk UKM siap untuk dikirimkan ataupun diambil sendiri oleh pemesan. Hal ini akan memudahkan pengguna sebagai pihak pembeli karena tidak perlu mendatangi sentra UKM untuk mendapatkan produk yang diinginkan (Prasmadewa dan Tanone 2016).

Pada aplikasi ini, pengguna dapat melihat info kerajinan anyaman purun melaluui smartphone mereka. Informasi yang diterima berisi menu Kerajinan, Profil Aplikasi, Galeri serta Petunjuk. Pengguna bisa melihat detail kerajinan yang berisi judul, foto, penjelasan singkat, alamat, dan lokasi. Seandainya 
Jurnal Mediteg

Volume 3, Nomor 1, Desember 2018

pengguna ingin berkunjung ke lokasi kerajinan di kelurahan Palam dengan bantuan peta yang ada di aplikasi tersebut.

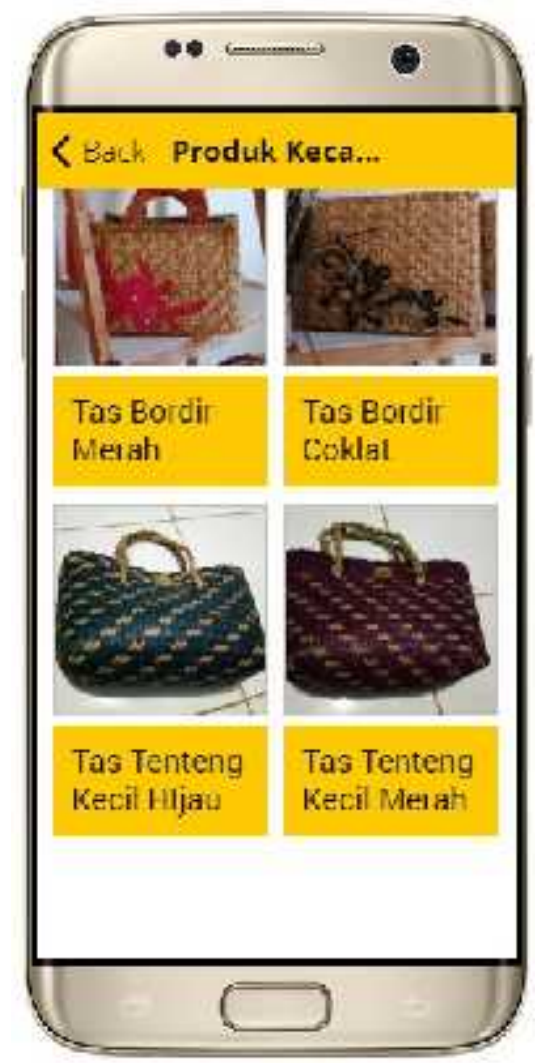

Gambar 1. Catalog produk kerajinan purun

Pada Gambar 1. Merupakan tampilan pada menu catalog, pengguna dapat melihat dan memilih produk kerajinan anyaman purun yang tersedia. Pengguna dapat melihat harga dan gambar yang lebih besar dengan mengklik gambar produk (Gambar 2). Setelah melhat gambar yang diinginkan, pengguna dapat mengklik link yang ada di gambar. Aplikasi android dibuat sesederhana mungkin, sehingga akan memudahkan pengrajin untuk segera merespon permintaan dari pengguna.
p-ISSN : 2548-7655

e-ISSN : 2614-0489

Aplikasi ini dapat dijalankan dengan spesifikasi Handphone minimal dengan sistem sebagai berikut.

1. Sistem operasi android

2. RAM $500 \mathrm{MB}$

3. Layar dengan resolusi $480 \times 800$ pixel.

Aplikasi penjualan kerajinan anyaman purun dibangun dengan teknologi mobile pada platform android. Aplikasi tersebut juga memiliki teknologi Location Based Service (LBS) dari Geographichal Positioning System (GPS).

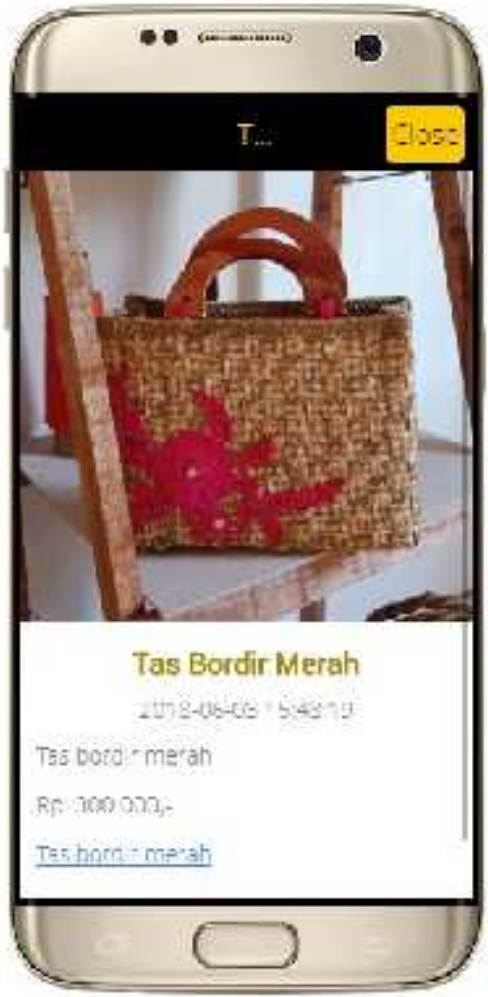

Gambar 2. Tampilan harga dan link

Pada kegiatan pelatihan penggunaan aplikasi, para pengrajin didampingi oleh putra mereka sehingga tidak kesulitan dalam melakukan transaksi dan update data produk. Namun pada aplikasi yang memang baru 
Jurnal Mediteg

Volume 3, Nomor 1, Desember 2018

pertama kali dibuat masih terdapat kekurangan, yaitu tampilan masih sederhana dan catalog produk yang belum lengkap. Meskipun demikian aplikasi yang telah dibuat sangat membantu para pengrajin.

Evaluasi kegiatan yang dilaksanakan menunjukkan bahwa penggunaan aplikasi android telah meningkatkan transaksi penjualan sebesar $70 \%$ dan terjadi peningkatan pendapatan sebesar $65 \%$ dari sebelum penggunaan android. Selain itu berdasarkan survei kepuasan konsumen, pada aplikasi android perlu ditambahkan fitur penilaian produk yang dikirimkan.

\section{KESIMPULAN}

Berdasarkan pada survei yang dilakukan selama kegiatan KKN berlangsung, dengan penggunaan aplikasi android terdapat peningkatan transaksi sebesar $70 \%$ dan peningkatan pendapatan sebesar 65\%. Pada aplikasi android perlu penambahan fitur penilaian barang yang dikirim.

\section{DAFTAR PUSTAKA}

Amelia Mn, Prasetyo Y, Maharani I. 2017. EUmkm: Aplikasi Pemasaran Produk Umkm Berbasis Android Sebagai Strategi Meningkatkan Perekonomian Indonesia. Pros Iding Snati F Ke-4 Tahun 2017 isbn: 978-602-1180-50-1

Gartner. Gartner Says Annual Smartphone Sales Surpassed Sales of Feature Phones

$$
\text { p-ISSN : 2548-7655 }
$$

e-ISSN : 2614-0489

for the First Time in 2013. http://www.gartner.com/newsroom/id /2665715, 2012. [Diakses 3 Agustus 2018].

Prasmadewa K, Tanone R. 2016. Perancangan Aplikasi Usaha Kecil Mikro dan Menengah Berbasis Android (Studi Kasus: Sentra UMKM Tingir LorSalatiga). Jurnal Teknik Informatika dan Sistem Informasi. Vol. 2 no. 3

Heyne, K. 1987. Tumbuhan Berguna Indonesia. Jilid I dan II. Terj. Badan Libang Kehutanan. Cetakan I. Koperasi karyawan Departemen Kehutanan Jakarta Pusat. 